\title{
Kualitas Madu Lokal Berdasarkan Kadar Air, Gula Total dan Keasaman dari Kabupaten Magelang
}

\section{Quality of Local Honey Based on Moisture Content, Total Sugar, and Acidity from Magelang Regency}

\author{
Devi Adityarini ${ }^{1 *}$, Sri Agung Widodo Suedy ${ }^{2}$, Sri Darmanti ${ }^{2}$ \\ ${ }^{1}$ Program Studi Biologi, Departemen Biologi, Fakultas Sains dan Matematika, Universitas Diponegoro \\ ${ }^{2}$ Departemen Biologi, Fakultas Sains dan Matematika, Universitas Diponegoro \\ *Email:deviadityarini96@gmail.com
}

Diterima 2 Februari 2020 / Disetujui 22 Februari 2020

\begin{abstract}
ABSTRAK
Madu merupakan cairan alami yang dihasilkan oleh lebah madu,berasal dari nektar bunga atau bagian lain dari tumbuhan. Madu dinyatakan memiliki kualitas baik apabila memenuhi standar kualitas madu. Kualitas madu dapat ditentukan berdasarkan kadar air, gula dan keasaman. Penelitian ini bertujuan untuk mengetahui kualitas madu lokal di Kabupaten Magelang. Pengambilan sampel secara purposive sampling dari lima wilayah Kabupaten Magelang, yaitu Desa Kaliurang, Ringinanom, Kaliabu, Munggangsari, danKebonrejo. Penentuan kadar air dan gula total dengan metode refraktometri, sedangkan keasaman dengan metode titrasi asam-basa. Analisis kadar air, gula total, keasaman dibandingkan dengan standar kualitas madu. Hasil uji kualitas madu menunjukkan nilai kadar air berkisar antara $20,72-31,72 \%$, gula total $66,33-77,89^{\circ}$ Brix, keasaman $37,12-271,35$ $\mathrm{ml} \mathrm{NaOH} / \mathrm{kg}$ di mana kualitas madu Desa Kaliurang dan Desa Munggangsari telah memenuhi standar SNI 013545-2013 dan U.S. Patent Application Publication.
\end{abstract}

Kata kunci:kualitas, Magelang, kadar air, gula total, keasaman

\begin{abstract}
Honey is a natural liquid produced by honey bees, derived from flower nectar or other parts of plants. Honey is declared to have good quality if it meets honey quality standards. The quality of honey can be determined based on water content, sugar, and acidity. This study aims to determine the quality of local honey in Magelang Regency. Sampling was done by purposive sampling from five regions of Magelang Regency, namely Kaliurang, Ringinanom, Kaliabu, Munggangsari, and Kebonrejo Villages. Determination of total water and sugar content by refractometry method, while acidity with acid-base titration method. Analysis of water content, total sugar, acidity compared to honey quality standards. Honey quality test results showed the value of water content ranged between $20.72-31.72 \%$, total sugar $66.33-77.89^{\circ}$ Brix, acidity $37.12-271.35 \mathrm{ml} \mathrm{NaOH} / \mathrm{kg}$ where the quality of Kaliurang village honey and Munggangsari Village has met SNI 01-3545-2013 and US standards Patent Application Publication.
\end{abstract}

Keywords: quality, Magelang, moisture content, total sugar, acidity

\section{PENDAHULUAN}

Madu adalah cairan alami yang dihasilkan oleh lebah madu dari sari bunga (floral nektar) atau bagian lain dari tanaman (ekstra floral nektar) (BSN, 2013). Madu mengandung sekitar 80-85 \% karbohidrat, $15-17 \%$ air, $0,3 \%$ protein, $0,2 \%$ abu,sejumlah kecil asam amino dan vitamin (Cantarelli et al., 2008). Madu telah dimanfaatkan sebagai bahan peningkat cita rasa (flavoring agent), selain itu madu berfungsi sebagai antioksidan, antimikroba, regulator gula darah, dan meningkatkan sistem imun (Purwadi, dkk., 2017).

Kualitas madu dapat menentukan umur simpan serta manfaat dari madu. Kualitas madu dapat ditentukan dengan pengukuran kadar air, kadar gula, dan keasaman. Kadar air pada madu berkaitan dengan proses fermentasi yang 
diakibatkan oleh khamir osmofilik. Kadar gula berpengaruh terhadap sifat fisikokimia madu seperti viskositas, laju kristalisasi, dan higroskopisitas (Korošec et al., 2016). Nilai keasaman madu menentukan cita rasa, aroma madu, serta sebagai penanda proses fermentasi oleh khamir (Korošec et al., 2017). Standar Nasional Indonesiatahun 2013 (SNI 01-3545-2013) menyatakan kualitas madu yang baik memiliki nilai kadar air maksimal 22\% dan nilai keasaman madu maksimal $50 \mathrm{ml} \mathrm{NaOH} / \mathrm{kg}$, sedangkan kadar gula total pada madu yang baik berdasarkan U.S. Patent Application Publication tahun 2011 berkisar antara 76-83 ${ }^{\circ}$ Brix berdasarkan (Sarig et al., 2011; BSN, 2013).

Penelitian mengenai kualitas madu lokal berdasarkan parameter kadar air, gula dan keasaman telah dilakukan, di antaranya oleh Khasanah, dkk. (2017) mengenai kualitas madu lokal Kabupaten Wonosobo menunjukkan bahwa kualitas madu terbaik dan mendekati standar berasal dari madu Desa Pringapus dengan kadar air $22,17 \%$, kadar gula $76,17{ }^{\circ}$ Brix serta keasaman $34,08 \mathrm{ml}$. Sementara itu, penelitian tentang kualitas madu lokal Kabupaten Mangelang belum pernah dilakukan.

Penelitian ini menggunakan madu lokal yang diambil dari 5 wilayah di Kabupaten Magelang, yaitu Desa Kaliurang, Desa Ringinanom, Desa Kaliabu, Desa Munggangsari dengan ternak lebah jenis lebah lokal (Apis spp.), dan Desa Kebonrejo dengan ternak lebah jenis lebah tanpa sengat atau klanceng (Meliponini). Pemilihan terhadap 5 wilayah ini dilakukan secara purposive berdasarkan perbedaan geografis dan terdapatnya peternak lebah madu.

Kabupaten Magelang memiliki keanakeragaman tumbuhan tinggi yang dapat digunakan sebagai sumber pakan lebah madu (BPS Kabupaten Magelang, 2017), sehingga berpotensi menjadi sentra budidaya lebah madu. Studi mengenai kualitas madu yang dipasarkan guna meningkatkan kepercayaan masyarakat sebagai konsumen, selain itu mampu memberikan informasi kepada peternak mengenai kualitas madu yang dihasilkan maupun meningkatkan nilai jual oleh peternak lebah. Penelitian ini penting dilakukan untuk mengetahui keanekaragaman jenis tumbuhan pakan lebah serta kualitas madu lokal dari beberapa wilayah budidaya di Kabupaten Magelang.

\section{METODE PENELITIAN}

Penelitian dilakukan di Laboratorium Biologi dan Struktur Fungsi Tumbuhan, Departemen Biologi, Fakultas Sains dan Matematika, Universitas Diponegoro. Pengambilan sampel madu lokal Magelang dilakukan secara purposive sampling pada beberapa peternak lebah di Kabupaten Magelang, yaitu Desa Kaliurang, Desa Ringinanom, Desa Munggangsari, Desa Kaliabu dan Desa Kebonrejo. Madu yang digunakan pada penelitian ini dipanen pada musim kemarau (Juni hingga Agustus 2018).

Alat dan bahan yang digunakan dalam penelitian yaitu refraktometer madu (RHB92ATC), timbangan digital, hotplate (Labinco model L-81), erlenmeyer, gelas ukur, pipet tetes dan pinset, madu lokal dari 5 wilayah di Kabupaten Magelang, $\mathrm{NaOH} 0,1 \mathrm{~N}$, asam oksalat $0,1 \mathrm{~N}$, indikator PP $1 \%$, akuades.

\section{Penentuan kadar air dan gula total terlarut}

Penentuan kadar air dan kadar gula total ditentukan dengan metode refraktometri menggunakan refraktometer madu (RHB-92ATC). Pengukuran dilakukan dengan cara mengkalibrasi alat dengan akuades, kemudian diteteskan madu sebanyak 2-3 tetes pada kaca prisma. Refraktometer kemudian diarahkan ke sumber cahaya lalu dilihat skala yang tertera pada alat. Nilai kadar air dinyatakan dalam persen (\%) (BSN, 2013), sedangkan nilai kadar gula total dinyatakan dalam satuan Brix $\left({ }^{\circ}\right.$ Brix $)$ (Berriel, 2018). Brix merupakan zat padat terlarut dalam suatu larutan yang dihitung sebagai sukrosa (Shachman, 2004). Standar nilai kadar air mengacu pada SNI 01-3545-2013dan nilai kadar gula total mengacu pada U.S. Patent Application Publication-2011 (Sarig et al., 2011).

\section{Penentuan keasaman}

Penentuan keasaman dengan metode titrasi berdasarkan SNI 01-3545-2013: sebanyak 10 gram madu dilarutkan dengan $75 \mathrm{ml}$ akuades dan ditambahkan 4 tetes indikator PP. Larutan dititrasi dengan $\mathrm{NaOH} 0,1 \mathrm{~N}$ sampai titik akhir atau 
perubahan warna yang tetap selama 10 detik. Volume titran yang dibutuhkan untuk mencapai titik ekuivalen kemudian dicatat. Pengukuran sampel diulang sebanyak tiga kali. Nilai keasaman dalam madu dihitung dengan menggunakan rumus:

Keasaman $(\mathrm{ml} \mathrm{N} \mathrm{NaOH} / \mathrm{kg})=\frac{\mathrm{a} \times \mathrm{b}}{\mathrm{c}} \times 1.000$

Keterangan :

$\mathrm{a}=$ volume $\mathrm{NaOH} 0,1 \mathrm{~N}$ yang digunakan dalam titrasi $(\mathrm{ml})$

$\mathrm{b}=$ normalitas $\mathrm{NaOH} 0,1 \mathrm{~N}$

$\mathrm{c}=$ bobot contoh $(\mathrm{g})$

(BSN, 2013)
Hasil pengukuran parameter kualitas madu (kadar air, kadar gula total dan keasaman) dibandingkan dengan standar kualitas madu SNI3545: 2013 serta U.S. Patent Application Publication-2011(Sarig et al., 2011; BSN, 2013.

\section{HASIL DAN PEMBAHASAN}

Penelitian ini bertujuan untuk mengetahui kualitas madu lokal dari 5 wilayah peternakan di Kabupaten Magelang, yaitu Desa Kaliurang, Desa Munggangsari, Desa Ringinanom, Desa Kaliabu, dan Desa Kebonrejo. Hasil pengukuran kualitas madu berdasarkan tiga parameter (kadar air, gula total dan keasaman) disajikan pada Tabel 2.

\section{Analisis dan Interpretasi Data}

Tabel 2. Rata-rata nilai kadar air, gula total, dan keasaman pada madu lokal dari wilayah yang berbeda

\begin{tabular}{lcccccc}
\hline Parameter & Kebonrejo & Ringinanom & Kaliabu & Kaliurang & Munggangsari & Standar \\
\hline $\begin{array}{l}\text { Kadar Air } \\
(\%)\end{array}$ & $31,72 \pm 0,54$ & $23,89 \pm 1,67$ & $22,17 \pm 0,84$ & $21,77 \pm 1,12$ & $20,72 \pm 1,57$ & $\begin{array}{c}\text { Maks. } \\
22^{*}\end{array}$ \\
$\begin{array}{l}\text { Gula } \\
\text { Total }\end{array}$ & $66,33 \pm 0,76$ & $74,11 \pm 2,22$ & $76,22 \pm 0,86$ & $76,78 \pm 1,02$ & $77,89 \pm 1,39$ & $76-83^{* *}$ \\
$\left(\begin{array}{l}\left.{ }^{\circ} \text { Brix }\right) \\
\text { Keasaman }\end{array}\right.$ & & & & & & \\
$\begin{array}{l}\text { (NaOH } \\
\text { ml/kg) }\end{array}$ & $271,35 \pm 50,82$ & $41,09 \pm 6,11$ & $87,44 \pm 4,90$ & $37,12 \pm 8,25$ & $40,74 \pm 9,07$ & $\begin{array}{c}\text { Maks. } \\
50^{*}\end{array}$ \\
$\begin{array}{l}\text { Jenis } \\
\text { Lebah }\end{array}$ & $\begin{array}{l}\text { klanceng } \\
\text { (Meliponini) }\end{array}$ & $\begin{array}{c}\text { lebah lokal } \\
\text { (Apis spp. }\end{array}$ & $\begin{array}{c}\text { lebah lokal } \\
\text { (Apis spp.) }\end{array}$ & $\begin{array}{c}\text { lebah lokal } \\
\text { (Apis spp.) }\end{array}$ & $\begin{array}{c}\text { lebah lokal } \\
\text { (Apis spp.) }\end{array}$ & \\
\hline Keterangan: $*$ SN tahun 2013 & & & & &
\end{tabular}

Keterangan: *: SNI tahun 2013

**: U.S. Patent Application Publication tahun 2011

\section{Kadar Air}

Hasil penelitian menunjukkan bahwa nilai kadar air dari sampel madu lokal Magelang berkisar antara 20,72\% hingga 31,72\% (Tabel 2). Madu berkualitas baik menurut SNI 01-3545-2013 memiliki nilai kadar air maksimal $22 \%$. Berdasarkan hasil penelitian kadar air pada kelima sampel, madu yang telah memenuhi standar adalah madu dari Desa Kaliurang dan Desa Munggangsari, sedangkan ketiga sampel lainnya memiliki nilai kadar air di atas standar.

Secara umum kadar air pada madu dipengaruhi oleh faktor-faktor lingkungan seperti cuaca dan kelembaban di dalam sarang, kondisi nektar, prosespemanenan, serta penyimpanan (Gariola et al., 2013). Rendahnya kadar air pada madu Desa Kaliurang dan Desa Munggangsari disebabkan karena tingkat kematangan madu yang dipanen telah sempurna ditandai oleh tertutupnya sarang oleh lapisan lilin, sedangkan madu Desa Ringinanom memiliki nilai kadar air melebihi standar dikarenakan pemanenan madu pada sarang yang masih muda. yang ditandai oleh tertutupnya sarang oleh lapisan lilin. Menurut ICMSF (2005), madu matang mengandung air sekitar 20\%. Penyegelan sarang dengan lilin bertujuan untuk mencegah terjadinya penyerapan air dari lingkungan karena madu bersifat higroskopis.

Kadar air dalam madu dapat dipengaruhi oleh sumber nektar tumbuhan yang dikumpulkan oleh lebah. Madu Desa Kaliabu memiliki nilai kadar air melebihi standar. Menurut Thohari, dkk. (2017), air pada sisiran madu berasal dari nektar yang telah mengalami pematangan oleh lebah. Proses 
penyimpanan juga mempengaruhi kadar air pada madu, kurang rapatnya wadah penyimpanan akan menyebabkan madu menyerap air dari lingkungan sehingga mengakibatkan kadar air meningkat.

Madu dari Desa Kebonrejo memiliki nilai rata-rata kadar air paling tinggi yaitu sebesar $31,72 \%$. Tingginya kadar air dapat disebabkan oleh jenis lebah yang dibudidayakan, yaitu lebah tanpa sengat (klanceng). Hal ini berkorelasi dengan hasil penelitian Souza et al. (2017), bahwa dibandingkan dengan madu Apis mellifera,madu dari lebah tanpa sengat memiliki nilai kadar air yang lebih tinggi.

Faktor lainnya yang mempengaruhi kadar air dalam madu yaitu kondisi lingkungan di wilayah peternakan. Suhu udara pada lima wilayah peternakan berkisar antara $23-27^{\circ} \mathrm{C}$, kelembaban udara berkisar antara 51-65\%, dengan ketinggian wilayah peternakan berkisar antara 281,09-1292,49 mdpl. Suhu udara lingkungan yang rendah serta kelembaban udara yang tinggi dapat menyebabkan madu menjadi lebih encer karena madu memiliki sifat higroskopis, sehingga kadar air pada madu menjadi meningkat. Menurut Savitri, dkk. (2017), kadar air yang tinggi menyebabkan terjadinya fermentasi madu sehingga menurunkan umur simpan serta kualitas madu.

\section{Kadar Gula Total}

Hasil penelitian menunjukkan nilai rata-rata kadar gula total pada madu dari lima lokasi berkisar antara 66,33-77,88 ${ }^{\circ}$ Brix (Tabel 2). Menurut U.S. Patent Application Publication, kadar gula total dalam madu yang baik berkisar antara $76-83{ }^{\circ}$ Brix (Sarig et al., 2011). Kadar gula total dinyatakan dalam satuan Brix ( ${ }^{\circ}$ Brix) merupakan zat padat terlarut dalam suatu larutan yang dihitung sebagai sukrosa (Parmitasari dan Hidayanto, 2013). Kadar gula dalam madu dapat dipengaruhi oleh tingkat kematangan, jenis lebah serta sumber nektar.

Berdasarkan hasil penelitian, kadar gula total pada sampel madu yang telah memenuhi standar adalah madu dari Desa Kaliabu, Desa Kaliurang dan Desa Munggangsari, untuk nilai fungsional madu dengan kadar gula tinggi menunjukkan bahwa madu berkualitas baik. Menurut Crane (1999), kadar gula total yang tinggi di dalam madu mampu mencegah pertumbuhan mikroba seperti khamir, sehingga mencegah terjadinya fermentasi. Evahelda et al. (2015) menyatakan, kandungan gula dalam madu mampu mempengaruhi rasa, aroma, dan umur simpan madu. Tinggi kadar gula menyebabkan tekstur madu menjadi lebih kental serta menghambat pertumbuhan mikroba.

Tingkat kematangan madu mampu mempengaruhi kadar gula pada madu. Rendahnya kadar gula pada madu Desa Ringinanom disebabkan oleh pemanenan yang dilakukan pada madu yang masih muda. Menurut Mahindru (2007), madu yang telah matang mengandung gula sekitar $80 \%$ serta kadar air kurang dari $22 \%$. Kandungan air yang berlebih dapat merangsang pertumbuhan mikroba untuk melakukan fermentasi, yang mana akan mendegradasi gula menjadi asam asetat, karbondioksida, dan air.

Jenis lebah juga dapat mempengaruhi kandungan gula dalam madu. Madu dari Desa Kebonrejo memiliki nilai rata-rata kadar gula total paling rendah, yaitu sebesar $66,33{ }^{\circ}$ Brix dimana lebah madu yang diternakkan adalah lebah tanpa sengat atau klanceng, hal ini sesuai dengan pernyataan Sousa et al. (2015) bahwa, kadar gula total pada madu lebah tanpa sengatumumnya lebih rendah dibandingkan dengan madu dari lebah Apis mellifera, sedangkan kadar airnya lebih tinggi.

Sumber nektar yang dikumpulkan oleh lebah menjadi salah satu faktor yang mempengaruhi kadar gula dalam madu. Menurut ICMSF (2005), kandungan gula pada nektar tanaman bervariasi berkisar antara 5-80\%. Kadar gula dalam nektar dapat dipengaruhi oleh kondisi lingkungan. Crane \& Walker (1985) menyatakan, kadar gula nektar meningkat melalui penguapan air terutama saat suhu lingkungan tinggi, sedangkan kadar gula akan menurun saat kelembaban lingkungan tinggi akibat penyerapan air dari lingkungan. Kadar gula yang cukup tinggi pada sampel terutama madu yang dihasilkan lebah lokal (Apis spp.), dapat disebabkan oleh pemanenan yang dilakukan di bulan Juni hingga Agustus yang merupakan musim kemarau di mana kadar gula pada nektar umumnya lebih tinggi dibandingkan dengan kadar air nektar.

\section{Keasaman}


Hasil penelitian menunjukkan bahwa nilai rata-rata keasaman pada sampel madu berkisar antara 37,12 ml NaOH/kg - 271,35 ml NaOH/kg. Nilai keasaman pada madu yang baik menurut SNI tahun 2013 memiliki maksimal $50 \mathrm{ml} \mathrm{NaOH} / \mathrm{kg}$. Madu yang memiliki nilai keasaman yang telah memenuhi standar yaitu sampel madu dari Desa Kaliurang, Desa Ringinanom, dan Desa Munggangsari (Tabel 2).Korošec et al. (2017) menyatakan, keasaman merupakan parameter penting dalam menentukan kualitas madu karena mempengaruhi cita rasa dan aroma, serta sebagai penanda proses fermentasi.

Kadar air merupakan salah satu faktor yang mempengaruhi keasaman dalam madu. Rendahnya keasaman madu dapat disebakan oleh rendahnya kandungan air serta indikasi belum terjadinya fermentasi. Madu Desa Kaliabu memiliki nilai keasaman melebihi standar, di mana kadar air pada sampel madu ini juga tinggi. Menurut Bellik \& Iguerouada (2014), madu dengan kadar air tinggi mampu memicu pertumbuhan khamir penyebab fermentasi dan meningkatkan keasaman madu. Korošec et al. (2017) menyatakan bahwa, tingginya nilai keasaman pada madu menandakan bahwa proses fermentasi oleh khamir osmofilik sedang berlangsung, proses ini menyebabkan kualitas madu menjadi menurun, sehingga secara fungsional sebagai bahan pangan juga akan menurun kualitasnya.

Madu yang dihasilkan oleh lebah tanpa sengat secara umum memiliki nilai keasaman lebih tinggi dibandingkan dengan madu lebah Apis mellifera (Souza et al. 2006), seperti pada sampel madu Desa Kebonrejo. Menurut Fadhilah dan Rizkika (2015), pemanenan madu klanceng umumnya dilakukan dengan memeras pot-pot sarang di mana terdapat pot polen, pot madu, serta tercampur dengan lilin dan propolis. Pot polen umumnya lebih banyak dibandingkan pot madu. Menezes et al. (2013) menyatakan, pot polen umumnya memiliki rasa asam karena polen yang disimpan lebah biasanya telah mengalami fermentasi, hal ini diduga menyebabkan nilai keasaman madu klanceng tinggi.

Komposisi vegetasi tanaman yang menjadi sumber pakan lebah juga menjadi faktor yang mempengaruhi keasaman madu. Menurut Sousa et al. (2016) dan Fatma (2017), keasaman madu berkaitan dengan kandungan asam organik yang terdapat di dalam madu, di mana kandungan asam organik ini bervariasi pada tiap jenis tumbuhan yang menjadi sumber pakan lebah serta jenis lebah penghasil madu.

\section{KESIMPULAN}

Kualitas madu lokal Magelang beragam antar wilayah peternakan lebah, nilai kadar air berkisar antara $20,72-31,72 \%$, nilai kadar gula total berkisar antara $66,33-77,88^{\circ}$ Brix, nilai keasaman berkisar antara 37,12-271,35 $\mathrm{ml} \mathrm{NaOH} / \mathrm{kg}$. Madu dengan kualitas berdasarkan nilai kadar air, gula total, dan keasaman yang mendekati SNI tahun 2013 dan U.S. Patent Application adalah madu Desa Kaliurang dan Desa Munggangsari.

\section{UCAPAN TERIMAKASIH}

Terima kasih kepada Fakultas Sains dan Matematika, Universitas Diponegoro yang telah membiayai penelitian ini berdasarkan Surat Penugasan Pelaksanaan Kegiatan Penelitian Sumber Dana Selain APBN DPA SUKPA Fakultas Sains dan Matematika, Universitas Diponegoro Tahun Anggaran 2018 dengan Nomor kontrak: 1754U/UN7.5.8/PG/2018 tanggal 2 April 2018.

\section{DAFTAR PUSTAKA}

Bellik, Y. and M. Iguerouada 2014. Honey in the Food Industry. P. 409-435 In: L. Boukraâ (Ed.). 2014. Honey in Traditional and Modern Medicine. CRC Press, Boca raton, FL..

Berriel, V. (2018). Carbon Stable-Isotope and Physicochemical Data as. Journal of Foods. $\quad 7(86)$ : 1-8. https://doi.org/10.3390/foods7060086

BPS Kabupaten Magelang. Statistik Daerah Kabupaten Magelang 2017. www.magelangkab.bps.go.id. Diakses 15 April 2018.

Badan Standarisasi Nasional (BSN). 2013. SNI 013545-2013. Madu. Badan Standarisasi Nasional, Jakarta. 
Cantarelli, M. A., Pellerano, M. A., Marchevsky, R. G., Camiña, E. J., \& M, J. (2008). Quality Of Honey From Argentina: Study Of Chemical Composition And Trace Elements . Resumen. Journal of the Argentine Chemical Society. 96(1-2): 3341. Diakses dari www.scielo.org.ar/pdf/jacs/v96n12/v96n1-2a04.pdf

Crane, Eva; Walker, P. (1985). Some Nectar Characteristics of Certain Important World Honey Sources. Pszczelnicze Zeszyty Naukowe. 29: 29-45. Diakses dari http://miesiecznikpszczelarstwo.pl/pzn/pl/node/401

Crane, E. 1999. The World History of Beekeeping and Honey Hunting. Routledge, New York.

Evahelda, Pratama, F., Malahayati, N., \& Santoso, B. (2017). The Changes of Moisture Content, $\mathrm{pH}$, and Total Sugar Content of Honey Originated from the Flowers of Bangka Rubber Tree during Storage. International Journal of Scientific Engeneering and Research (IJSER). 5(5): 2015-2018. Diakses dari https://www.ijser.in/IJSER151372

Fadhilah, R. dan K. Rizkika. 2015. Laba: Lebah Tanpa Sengat. Depok, PT Trubus Swadaya.

Fatma, I. I., Haryanti, S., \& Suedy, S. W. A. (2017). Uji kualitas madu pada beberapa wilayah budidaya lebah madu di kabupaten pati. Jurnal Biologi. 6(2): 58-65. Diakses dari https://ejournal3.undip.ac.id/index.php/bi ologi/article/view/19538/18528

Gariola, A., Tiwari, P., \& Tiwari, J. K. (2013). PHYSICO-CHEMICAL PROPERTIES OF APIS CERANA- INDICA $F$. HONEY FROM UTTARKASHI DISTRICT OF UTTARAKHAND ,. Journal of Global Biosciences. 2(1): 20 $25 . \quad$ Diakses dari http://mutegens.co.in/jgb/vol.02/1/04.pdf

Gupta, R. 2011. Plant Taxonomy: Past, Present, and Future. The Energy and Resources Institute (TERI), New Delhi.
ICMSF (International Comission on Microbiological Specifications for Foods). 2005. Sugar, Syrups, and Honey. P. 522-543. In: Microorganisms in Foods 6: Microbial Ecology of Food Commodities, 2nd Edition. Kluwer Academic, New York.

Khasanah, R., S. Parman, S. W. A. Suedy. 2017. Kualitas Madu Lokal Dari Lima Wilayah di Kabupaten Wonosobo. Jurnal Biologi. 6(1): 29-37. Diakses dari https://ejournal3.undip.ac.id/indeks.php/b iologi/article/view/19520

Korošec, M., U. Kropf, T. Golob, J. Bertoncelj. 2016. Functional and Nutritional Properties of Different Types of Slovenian Honey. P. 323-336. In: K. Kristbergsson, S. Ötles (Eds.). Functional Properties of Traditional Foods. Springer Science and Business Media, New York.

Korošec, M., R. Vidrih, J. Bertoncelj. 2017. Slovenian Honey and Honey Based Products. Ch. 7. In: R. M. S. Cruz and M. C. Vieira (Eds.). Mediterranean Foods: Composition and Processing. CRC Press, Boca Raton, FL.

Mahindru, S. N. 2007. Beekeping. APH Publishing Company, New Delhi.

Menezes, C., A. Vollet-Neto, F. A. F. L. Contrera, G. C. Venturieri, V. L. ImperatrizFonseca. 2013. The Role of Useful Microorganisms to Stingless Bees and Stingless Beekeeping. P. 153-171. In: P. Vit, S. R. M. Pedro, D. Roubik (Eds.). Pot-Pollen: A Legacy of Stingless Bees.Springer Science and Business Media, New York.

Thohari, I., Mustakim, M. C. Padaga, P. P. Rahayu. 2017. Teknologi Hasil Ternak. UB Press, Malang.

Parmitasari, P. dan E. Hidayanto. 2013. Analisis Korelasi Indeks Bias Dengan Konsentrasi Sukrosa Beberapa Jenis Madu Menggunakan Portable Brix Meter. 1(5): 191-198. Diakses dari https://ejournal3.undip.ac.id/indeks.php/b fd/article/view/3874 
P urwadi, L. E. Radiati, H. Evanuarini, R. D. Andriana. 2017. Penanganan Hasil Ternak. UB Press, Malang.

Sarig, Y., Sarig, O., Siegler, E. 2011. U.S. Patent Application Publication: SEMI-SOLID HONEY-BASEDPRODUCTS. United States. Diakses dari https://patents.google.com/patent/WO20 $\underline{10052703 \mathrm{~A} 1}$

Savitri, N. P. T. 2016. Identifikasi Polen dan Kualitas Madu Dari Beberapa Wilayah di Kabupaten Temanggung. Skripsi. Universitas Diponegoro, Semarang.

Savitri, N. P. T., Hastuti, E. D., and Suedy, S. W. A. 2017. Kualitas Madu Lokal Dari Beberapa Wilayah di Kabupaten Temanggung. Buletin Anatomi dan Fisiologi. Vol 2 (1): 58-66. Diakses dari https://ejournal2.undip.ac.id/indeks.php/b af/article/view/1094

Shachman, M. 2004. The Soft Drinks Companion: A Technical Handbook for the Beverage Industry. CRC Press, Boca Raton, FL..

Sousa, J. M., Souza, E. L., Marques, G., Benassi, M. T., Gullón, B., Pintado, M. M., Magnani, M. 2016. Sugar profile, physicochemical and sensory aspects of monofloral honeys produced by different stingless bee species in Brazilian semiarid region. LWT-Food Science and Technology. 65: 645-651. https://doi.org/10.1016/j.lwt.2015.08.058

Souza, B., Roubik, D., Barth, O., Heard, T., Enríquez, E., Carvalho, C., Villas-Bôas, J., Marchini, L., Locatelli, J., PersanoOddo, L., Almeida-Muradian, L., Bogdanov, S., Vit, P. 2006. Composition of Stingless Bee Honey: Setting Quality Standards. Interciencia. 31 (12); 867-875. Diakses dari www.ihcplatform.net/interciencia06.pdf 